\title{
Effect of silicon on tomato production in semi- controlled conditions in the Colombian Caribbean
}

\begin{abstract}
Silicon has been used in crop management programs, under the premise that it participates in the hardening of plant cell walls. In this sense, this research has been implemented in order to know how much silicon influences the quality of tomato fruit, given that this element theoretically fulfills metabolic and structural functions in the physiology of plants, for which, in this study, the effect of various doses of silicon on tomato yield was evaluated, using silicon dioxide as a source. The trial was established under a completely randomized design, with four treatments or doses of Silicon $(0,20,40$ and $60 \mathrm{~g} / \mathrm{plants}$ as $\mathrm{SiO}_{2}$ ). The silicon was added 20 days before sowing, the crop management was done with cultural practices. Performance components were evaluated. It was found that the silicon fertilization did not influence the yield components, on the contrary, it hints that the applied silicon doses can affect the decrease of the yields of this crop in acid soil conditions.
\end{abstract}

Volume 7 Issue 5 - 2020

\author{
Luis Fernando Acosta Pérez,' Eliecer \\ Cabrales Herrera ${ }^{2}$ \\ Universidad Nacional Abierta, Distancia UNAD, Colombia \\ ${ }^{2}$ Professor soils area, Universidad de Córdoba, Colombia
}

Correspondence: Eliecer Cabrales Herrera, Professor soils area, Universidad de Córdoba, Montería, Córdoba, Colombia, Email ecabralesh@correo.unicordoba.edu.co

Received: May 31, 2020 | Published: September 21, 2020

Keywords: silica, yield, fertilization, Solanum lycopersycum, beneficial

\section{Introduction}

Tomato (Solanum lycopersicum L.) is one of the most important commercial crops in the world. ${ }^{1}$ In Colombia, the tomato is planted in almost all regions of the country, although it grows successfully in hot climates with good yields, the largest planting areas are in temperate climates. In the Caribbean Region it is planted in small areas (less than 1 hectare) and without qualified technical assistance, so the production of this crop for the year 2018 was 2989 tons with an average yield of 13.6 t/ha. ${ }^{2}$ It is a short cycle crop (100-110 days), it can be sown at any scale, it adapts to different types of soils, its fruit is in high demand in the local, national and international market, is consumed as fresh fruit and industrialized. Tomato cultivation requires the availability of mineral elements in the soil, it is they that influence the development of the plant, giving it health, vigor and conditions for production. These elements directly influence the biochemical and physiological processes of the plant: photosynthetic activity and rate of translocation of photoassimilates. ${ }^{3-6}$ This plant extracts for its metabolism the macroelements (N, P, K, Ca, Mg and $\mathrm{S}$ ), as well as the microelements (Fe, $\mathrm{Mn}, \mathrm{B}, \mathrm{Mo}, \mathrm{Cu}, \mathrm{Zn}$ and $\mathrm{C}$ ), all essential in the development of the same, however, authors like Jarosz affirm that tomato extracts silicon as a beneficial element and that it fulfills multiple functions in the plant, among which, cell wall hardness is highlight.

Also, authors report satisfactory results in various crops (soybeans, corn, potatoes, coffee and strawberries), mainly in the increase in the production of these cultivars, likewise report that decreases in leaf transpiration, increasing efficiency in the use of nutrients immobile as calcium, iron, zinc, manganese and copper, which also provide greater resistance to attack by pests and diseases in plants..$^{7-13}$ According to Reuscher ${ }^{14}$ considered that SINIP2-1 could be a silicon transporter in tomato plant, but Deshmukh ${ }^{15}$ found that SINIP2-1 does not exert a silicon transport function in this crop. Therefore, the tomato plant is still considered a passive absorption plant for silicon, which is opposed to silicon accumulators. Silicon has been used in crop management programs, with the premise that it participates in the hardening of plant cell walls and influences the synthesis of toxins in the plant's biochemical response, as well as in the gene expression of defense proteins. ${ }^{7}$ However, the effect of silicon on tomato cultivation remains a subject of study, since tomato fruits require high hardness on their walls to counteract pathogen attacks, so many researchers have made it known. ${ }^{16-19}$

To date, there is no information available on the effect of silicon on tomato cultivation in the Colombian Caribbean region, so farmers in the area are interested in knowing if this element has positive effects on the yield of this crop. In order to contribute to answering this concern, this research was established in which different doses of silicon applied to the soil were evaluated, using silicon oxide as a source, and production parameters of the tomato crop were evaluated under semi-controlled conditions.

\section{Materials and methods}

The investigation was carried out under semi-controlled conditions in Sincelejo (Sucre)-Colombia, North Caribbean Coast, geographical coordinates $9^{\circ} 31^{\prime}$ ' $08.54^{\prime}$ 'North latitude and $75^{\circ} 36^{\prime} 72.07^{\prime \prime}$ '. West longitude, warm climate, average annual temperature of $29^{\circ} \mathrm{C}$, altitude of 174 masl, average relative humidity of $78 \%$ and average annual precipitation between 900 and $1200 \mathrm{~mm} .{ }^{20}$ The soil of the study area has a loamy sandy texture, considered to be extremely acidic $(\mathrm{pH}=4.4)$, so it was necessary to pretreat the soil with an equivalent dose of 3.0 t.ha $^{-1}$ of commercial lime $(\mathrm{CaO}$ of $37.05 \%$ and $5.35 \%$ $\mathrm{MgO}$ ), it was left in incubation for 40 days. The dose of 3 t.ha ${ }^{-1}$ was made based on previous tests carried out in the area, ${ }^{21,22}$ where the $\mathrm{pH}$ goes from 4.3 to 5.5, which in turn decreases Visibly interchangeable acidity, making the soil a less damaging medium for the development of any cultivar. This soil, due to its sandy texture, contributes to rapid drainage, which in turn leads to the washing of the few interchangeable bases it has, making them more deficient. However, the application of the amendment provides calcium and magnesium. The other nutrients needed they were applied as a complement in the fertilization plans, achieving a cultivar with good leaf and fruit development. 
The seedbed was made in a mixture of soils: sand: compost, in a ratio of 2:1:1, which was sterilized by insolation for 3 days (approximately 10 hours of sunshine per day) in layers of $10 \mathrm{~cm}$ thick and covered with plastic black to store more heat. Then it was uncovered and left to rest for 2 days, later and after aeration, it was filled the $200 \mathrm{ml}$ glasses of capacity and sowed in them, depositing 3 seeds in each glass, which had a germination and emergence greater than $90 \%$. The transplant was made when the tomato seedlings were $20 \mathrm{~cm}$ high and three true leaves (20 days after the emergency), this transplant was done in nursery bags with a capacity of $20 \mathrm{~kg}$, depositing the entire contents of the glass in each bag, these were located at a distance of $0.8 \mathrm{~m}$ by $0.6 \mathrm{~m}$. The treatments consisted of the silicon doses $(0,20,40$ and 60 $\mathrm{g}$ of $\mathrm{SiO}_{2}$ per plant), this dose was expanded and incorporated three
(3) days before transplantation, in the first $5 \mathrm{~cm}$ depth, the doses were selected with based on the studies carried out by Cao. ${ }^{23}$

The fertilization was made based on the results of the chemical analysis of soils (Table 1): $120 \mathrm{~kg} \mathrm{ha}^{-1}$ of nitrogen (source Urea at $46 \%$ $\mathrm{N}$ ), applied in a fractional way in three (3) doses at 15, 30 and 45 days after transplant; $80 \mathrm{~kg} \mathrm{ha}^{-1}$ of $\mathrm{P}_{2} \mathrm{O}_{5}$ (source DAP 18-46-0), applied in two fractions, the first in pre-seeding and the second 30 days after transplant; $80 \mathrm{kgha}^{-1}$ of $\mathrm{K}_{2} \mathrm{O}(60 \% \mathrm{KCl}$ source $)$, its application was made in two fractions, at the time of sowing and the second 30 days after transplantation. For the supply of minor elements, a complete foliar fertilizer was used, with applications on days 15,30 and 45 after sowing, spriunked a solution with a concentration of $1 \mathrm{ml} \mathrm{L}^{-1}$.

Table I Results of the physical-chemical analysis of soils used in the investigation

\begin{tabular}{lllllllllll}
\hline $\mathbf{p H}$ & $\mathbf{M O}$ & $\mathbf{P}$ & $\mathbf{C a}$ & $\mathbf{M g}$ & $\mathbf{N a}$ & $\mathbf{K}$ & $\mathbf{A l}$ & \%A & \%L & \%Ar \\
\hline- & $\%$ & $\mathrm{mg} / \mathrm{kg}$ & $\mathrm{cmol}+/ \mathrm{kg}$ & & & \multicolumn{5}{c}{ Loamy sand } \\
4,4 & 0,33 & 5,9 & 1,2 & 0,8 & 0,4 & 0,01 & 8,9 & 82,5 & 14,3 & 3,2 \\
\hline
\end{tabular}

The cultural management of the tomato crop was carried out: manual weeding, there was no need to apply pesticides to manage pests and diseases. The culture was kept hanging on single wire strands of 8gauge wire and plants tied with nylon, the tutors $3.0 \mathrm{~m}$ apart and a height of $2.5 \mathrm{~m}$ above the ground level, which allowed the ventilation of the cultivation system. The harvest or recolection of the fruit was done manually and daily, the fruits that exhibited the appearance of a reddish color were harvested. In these fruits, the following variables were measured: harvested fruits, fruit weight, fruit dimensions and yield. The trial was established in a completely randomized design (DCA), with five treatments and three repetitions. The information obtained was stored in excel tables and processed with the SAS version 9.0 statistical program, was done analysis of variance and regression at $5 \%$ probability. ${ }^{24}$

\section{Results and discussion}

Yields components: For the harfarmvested fruits, the analysis of variance showed highly significant differences between the treatments (Table 2). The fit of the model is good, at a significance level of $1 \%$, which suggests that $87.63 \%$ of the variability of the data is explained by the model. Regarding the graphic behavior of the data, it can be seen that there is a quadratic adjustment for its modeling (Figure 1). Compared to the control treatment, a slight increase in the number of fruits harvested can be seen when $20 \mathrm{~g}$ of silicon per plant were applied, from this dose, the variable is dominated by a negative opening parabola that shows a decreasing trend of the same. This reduction in the amount of fruits harvested is probably due to the nutritional imbalance caused by Silicon or by the accompanying ions (calcium, potassium and sodium) that compete for the same absorption sites of other nutrients, in addition, so hints that silicon in the presence and sufficiency of calcium and magnesium (applied in liming), has no role in tomato yields. ${ }^{25-28}$

It is possible that this soil due to the high content of sand, is a contributor of silicon, however, the literature shows that this silicon contained in the sands is not bio soluble, therefore, it will not be available to plants. However, this condition of good drainage, which leads to the loss of nutritional elements in the soil, could have influenced the decrease in the number of fruits harvested, which agrees with Nurzynski ${ }^{29}$ who found that tomato plants cultivated in sandy soils decreased the amount of fruits to be harvested, possibly due to low availability of nutrients in this type of soil.

Fruit-weight, in this variable was not observed statistically significant effect of the treatments (Table 2), this similarity can be seen in Figure 2, where it can be seen that superiors doses of $20 \mathrm{~g}$ of silicon/plant can induce an improvement in the tomato fruit weight, but without statistical significance. This similarity between the treatments indicates that the silicon fertilization, under the edaphoclimatic conditions of the investigation, does not exert a positive effect on the weight of the fruit, noting the same weight of the fruit with or without its application, that is to say that for the increase in weight of the fruit, silicon does not fulfill this function. According to this, Peluzio $^{30}$ states that when the fruit begins to grow and ripen, the content of water and minerals increases, when the silicon is assimilable in sufficient quantity, it can be transported (via phloem) from the leaves goes to the fruit, along with other photo assimilates that occur in photosynthesis, a condition that possibly did not occur and perhaps has accumulated in the roots or the amount used in the test was not sufficient.

Table 2 Mean squares and significance levels of the variables evaluated in tomato

\begin{tabular}{lllllll}
\hline F.V & D.F & HF & FW & FL & FD & Yield \\
\hline Silicio & 3 & $189,33^{* *}$ & $15,17 \mathrm{~ns}$ & $11,83 \mathrm{~ns}$ & $4,02 \mathrm{~ns}$ & 123,2 ** \\
Error & 8 & 20,08 & 5,88 & 3,38 & 2,18 & 16,65 \\
C.V. (\%) & & 12,22 & 5,33 & 4,39 & 4,38 & 12,31 \\
R $^{2}$ & & 0,78 & 0,49 & 0,57 & 0,41 & 0,74
\end{tabular}

GL, degrees of freedom; HF, harvested fruits; FW, fruit weight; FL, fruit length; FD, fruit diameter; *, significant; **, highly significant; ns, not significant 


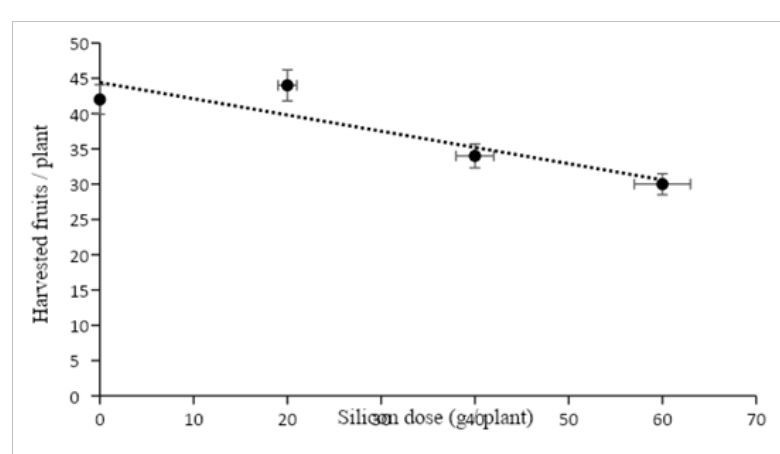

Figure I Effect of Silicon doses on the harvested tomato fruits.

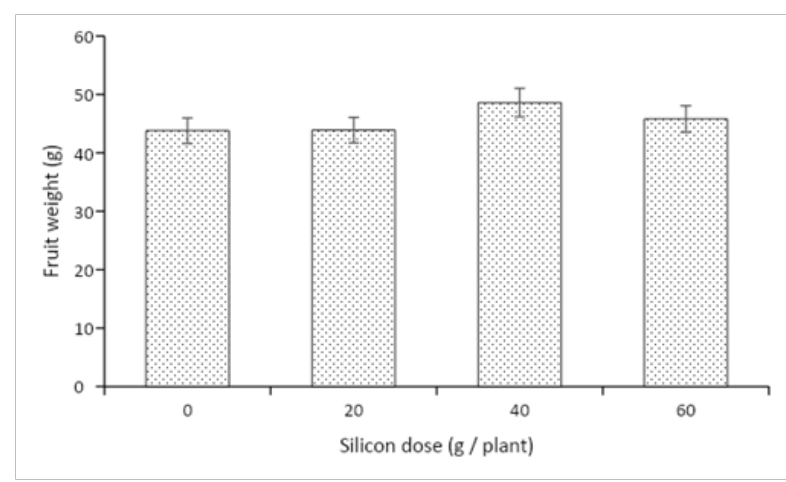

Figure 2 Effect of silicon doses on the weight of tomato fruit.

Regarding the dimensions of the fruit, the analysis of variance showed that there is no statistical difference between the treatments (Table 2). Both for the diameter and the length of the fruit the treatments are statistically similar (Figure 3). This similarity in the dimensions of the fruit when it was fertilized with silicon, indicates that this element is not sufficient to improve said characteristics, that is, for the conditions in which the research was carried out, it is not feasible to fertilize with silicon to improve the size of the fruit. tomato fruit. The no difference between the control treatment and the other treatments, possibly due to the fact that the silicon did not influence that the fruits received the photo assimilates that are produced in the leaves and that contain soluble solids, therefore, the fruit did not have differential elongation.

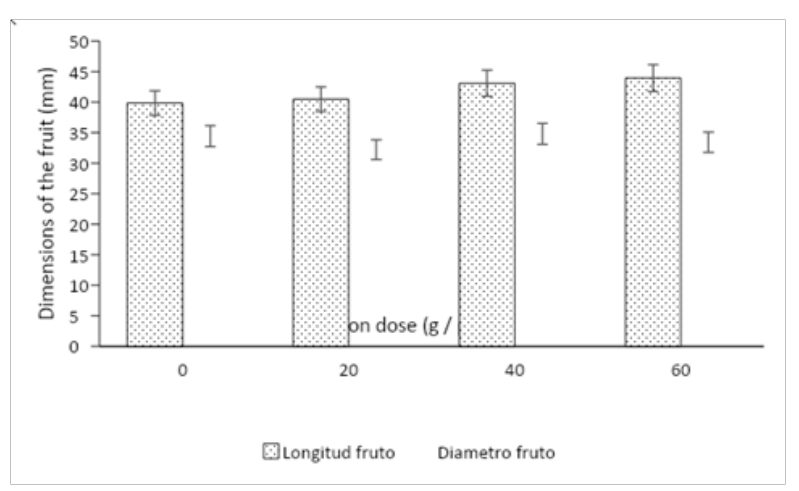

Figure 3 Effect of silicon doses on tomato fruit dimensions in Colombian Caribbean conditions.

The yield behavior is presented in Figure 4, the trend is adjusted to a quadratic order model with statistical significance. The analysis of variance showed that there are significant differences between the treatments, being the $\mathrm{T} 2$ treatment $(20 \mathrm{~g}$ of silicon/plant) where the highest yield is obtained, surpassing the control treatment (without application). With the increase of the silicon dose, after $20 \mathrm{~g} / \mathrm{plant}$, a decrease in the yield is observed, a condition to keep in mind in the fertilization plans with this element. Superiors doses that above $20 \mathrm{~g} /$ plant may be excess for tomato cultivation, which in turn could have caused deficiency of other elements, such as magnesium and phosphorus, which meant significant losses in production. In this sense, Fernandes \& Souza ${ }^{25}$ indicate that high doses of silicon reduce the amount of fruit and therefore productivity, a fact that is basically related to the nutritional imbalance caused by silicon excesive or by the accompanying calcium, potassium ions and sodium that compete for the same nutrient sites. ${ }^{24-27}$

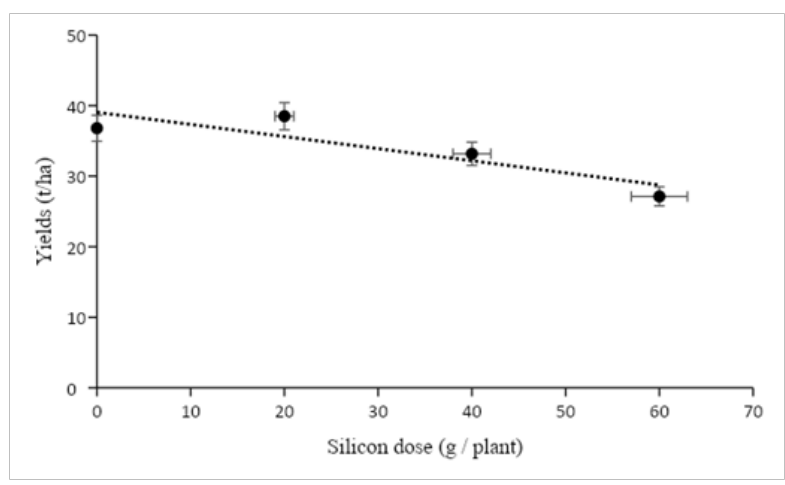

Figure 4 Effect of Silicon doses on tomato crop yield in edaphoclimatic conditions of the Colombian Caribbean.

The results of this investigation agree with those reported by Marodin, ${ }^{24-34}$ who did not manage to increase the yields with the application of silicon to the soil, so they assume that the absence of significant results is possibly due to the initial content of silicon in the soil or enough calcium available.

\section{Conclusions}

In acidic soils, silicon in the presence of calcium and magnesium does not influence the number, size and weight of the tomato fruit, however, a low dose $(20 \mathrm{~g} / \mathrm{plant})$ may be significant to improve the yield of the tomato crop in conditions of the Colombian Caribbean, high doses of silicon, induce a decrease in yields.

\section{Acknowledgments}

None.

\section{Conflicts of interest}

This manuscript was prepared and reviewed with the participation of the authors, who declare that there is no conflict of interest that jeopardizes the validity of the results presented.

\section{Funding}

None.

\section{References}

1. Ronga D, Francia E, Fulvia Rizza, et al. Changes in yield components, morphological, physiological and fruit quality traits in processing tomato cultivated in Italy since the 1930's. Scientia Horticulturae. 2019;257:108726. 
2. Agronet. Information and Strategic Communication Network of the Agricultural Sector - AGRONET Colombia. 2020. Ministry of Agriculture and Rural Development. Statistical Yearbook of the Agricultural Sector. 2020.

3. Ferreira NC, EP Vendruscolo, A Seleguini, et al. Growth, production and quality of tomato fruits in dense cultivation using paclobutrazol. Rev Colomb Cienc Hortic. 2017;11(1):72-79.

4. Ma J, Yamaji N. Functions and transport of silicon in plants. Cellular and Molecular Life Sciences. 2008;65(19):3049-3057.

5. Ma JF, Yamaji N, Mitani-Ueno N. Transport of silicon from roots to panicles in plants. P Japn Acad. 2011;87(7):377-385.

6. Ferreira M, Ferreira G, Fontes P, et al. Tomato quality as a function of nitrogen doses and organic fertilization in two seasons. Brazilian Horticulture. 2006;24:141-145.

7. Wang M, L Gao, S Dong, et al. Role of silicon on plant-pathogen interactions. Front Plant Sci. 2017;8:701.

8. Meharg C, Meharg AA. Silicon, the silver bullet for mitigating biotic and abiotic stress, and improving grain quality, in rice? Environ Exp Bot. 2015;120:8-17.

9. Mattei D, CR Dias-Arieira. Different sources of silicon in the embryonic development and in the hatching of Meloidogyne javanica. Afr J Agric Res. 2015;10(52):4814-4819.

10. Habibi G, Norouzi F, Hajiboland R. Silicon alleviates salt stress in pistachio plants. Prog Biol Sci. 2014;4(2):189-202.

11. Melo TA, IMRS Serra, GS Silva, et al. Natural products applied for the management of Meloidogyne incognita in tomato plants. Summa Phytopathol. 2012;38(3):223-227.

12. Li P, Song A Li, Z Fan, et al. Silicon ameliorates manganese toxicity by regulating manganese transport and antioxidant reactions in rice (Oryza sativa L.). Plant Soil. 2012;354(1-2):407-419.

13. Oliveira RM, RCF Ribeiro, AA Xavier, et al. Effect of calcium and magnesium silicate on the reproduction of Meloidogyne javanica and development of silver dwarf banana seedlings. Rev Bras Frutic. 2012;34(2):409-415.

14. Reuscher S, Akiyama M, Mori C, et al. Genome-wide identification and expression analysis of aquaporins in tomato. PLoS One. 2013;8(11): $1-13$.

15. Deshmukh RK, Vivancos J, Ramakrishnan G, et al. A precise spacing between the NPA domains of aquaporins is essential for silicon permeability in plants. Plant J. 2015;3(3):489-500.

16. Haynes RJ. A contemporary overview of silicon availability in agricultural soils. J Plant Nutr Soil Sci. 2014;177: 831-844.

17. Meena VD, Dotaniya ML, Coumar V, et al. A case for silicon fertilization to improve crop yields in tropical soils. P Natl Acad Sci. India; 2014.

18. Zhu Y, Gong H. Beneficial effects of silicon on salt and drought tolerance in plants. Agron Sustain Dev. 2014;34(2):455-472.
19. Haghighi M, Afifipour Z, Mozafarian M. The Alleviation Effect of Silicon on Seed Germination and Seedling Growth of Tomato Under Salinity Stress. Vegetable crops research bulletin. 2012;76:119-126.

20. Correa R, Carrillo L. System of environmental indicators of Colombia. Colombia: Hydrology, Meteorology and Environmental Studies Institute -IDEAM. 2013.

21. Acosta LF, Caro JD, Cabrales EM. Effect of the application of Calcium on the growth of the tomato crop (Lycopersicon esculentum, thousand) in an acid soil of Sucre. In: JL Burgos \& EM Cabrales, editors. Sowing system and efficient use of resources. Sincelejo, Colombia: Editorial CECAR. 2019. p. 139-158.

22. Acosta LF, Caro JD, Cabrales EM. Alternative tomato for small producers. Montería, Colombia: Editorial Zenú; 2018. p. 59-64.

23. Cao BL, Li WQ, Xu K. Effect of silicon on photosynthesis and fluorescence characteristics of tomato leaves under drought stress. $J$ Plant Nutr. 2016;22(2):495-501.

24. Marodin JC, Resende JTV, Morales RGF, et al. Yield of tomato fruits in relation to silicon sources and rates. Horticultura Brasileira. 2014;32(2):220-224.

25. Fernandes MS Souza. Nutrient absorption. In: Fernandes MS, editor. Mineral plant nutrition. Viçosa: Brazilian Society of Soil Science. 2006. p.115-152.

26. Korndörfer GH, Pereira HS, Camargo MS. Calcium and magnesium silicates in agriculture. Technical bulletin. Uberlândia: GPSi/ICIAG/ UFU; 2002;1:23.

27. Korndörfer GH, Pereira HS, Nolla A. Silicon analysis: soil, plant and fertilizer. Uberlândia: GPSi-ICIAG-UFU; 2004.

28. Ludwig F, Behling A, Schmitz JA. Silicon in the production and phytosanitary quality of tomatoes (Lycopersicum esculentum). Scientia Agraria Paranaensis. 2015;14(1):60-66.

29. Nurzynski J, Jarosz Z. The nutrient content in substrates and leaves of greenhouse tomato. Acta Sci Pol Hortorum Cultus. 2012;11(6):35-45.

30. Peluzio JM, Casali VW, Lopes NF, et al. Spring and drain behavior in tomato after apical pruning above the fourth cluster. Agrotechnical Science. 1999;23:510-514

31. Jarosz Z. The effect of silicon application and type of medium on yielding and chemical composition of tomato. Acta Sci Pol Hortorum Cultus. 2014;13(4):171-183.

32. Lana RMQ, Korndörfer GH, Zanão JLA, et al. Effect of calcium silicate on productivity and silicon accumulation in tomato. Bioscience Journal. $2003 ; 19(2): 15-20$

33. Pereira HS, Vitti GC, Korndörfer GH. Behavior of different sources of silicon in soil and in tomato culture. Brazilian Journal of Soil Science. 2003;27(1):101-08.

34. Pereira HS, Vitti GC. Effect of the use of schist on chemical characteristics of soil and on tomato nutrition. Horticultura Brasileira. 2004;22(2):317-322. 